\title{
Finite element computational dynamics of rotating systems
}

\author{
A bibliography (1994-1998)
}

\author{
Jaroslav Mackerle \\ Linköping Institute of Technology, Department of \\ Mechanical Engineering, S-581 83 Linköping, \\ Sweden
}

Received 19 July 1999

Revised 29 July 1999

This bibliography lists references to papers, conference proceedings and theses/dissertations dealing with finite element analysis of rotor dynamics problems that were published in 1994-1998. It contains 319 citations. Also included, as separate subsections, are finite element analyses of rotor elements - discs, shafts, spindles, and blades. Topics dealing with fracture mechanics, contact and stability problems of rotating machinery are also considered in specific sections. The last part of the bibliography presents papers dealing with specific industrial applications.

\section{Introduction}

The information is the most valuable, but least valued, tool the professional has. The output of scientific papers is growing and it is becoming more difficult to be fully up-to-date with all the relevant information. It is also known that a number of channels that researchers/practical engineers have at their disposal for information retrieval increases fast but it is questionable if researchers/practical engineers are willing to spend the time necessary to look for information. It has been pointed out that in engineering, informal knowledge channels are the most frequently used means of obtaining information. Many professionals prefer to rely on personal judgment or on the wisdom of their colleagues whenever they have problems to solve. Hopefully, it is the author's expectation that this bibliography will save time for readers looking for information dealing with subjects described below.

Modern rotating systems, often operating under extreme conditions and performing demanding tasks, are a prime machinery for transporting momentum, mass, and heat in many engineering systems. To understand the dynamics of these systems is very important in the design process as well as in the requirements to enhance the reliability and operational efficiency of these machines. In the design stage it is necessary to predict the dynamic behavior of rotor systems in bending and torsion, today frequently computed by using finite element techniques. This is the main subject of this bibliography. Topics dealing with fracture mechanics, contact and stability problems of rotating machinery are also considered in separate sections.

This bibliography provides a list of references on finite element dynamic analysis of rotating systems and their elements. General solution techniques as well as problem-specific applications are included. The entries have been retrieved from the author's database, MAKEBASE [1,2]. The references have been published in scientific journals, conference proceedings, and theses/dissertations between 1994-1998. They are sorted in each category alphabetically according to the first author's name. If a specific paper is relevant for several subject categories, the same reference can be listed under respective section headings, but the interested reader is expected to consider also areas adjacent to his/her central area of research. Listed references are grouped into the following sections and subsections:

- rotors and their elements (rotors, discs, shafts, spindles, blades)

- fracture mechanics and fatigue

- contact and contact-impact problems

- stability analysis

- specific industrial applications

Not included in the bibliography: drilling shafts, bearings, seals, passive/active vibration control of rotor systems, optimization problems. 


\section{Rotors and their elements}

The basic elements of a rotor are the disc, the shaft, the bearings and the seals. In this section of the bibliography listed papers are dealing with dynamic finite element analyses of rotors and their elements, with emphasis on their characteristics and behavior. Free and forced vibrations are studied. A rotating shaft is typically modelled as a series of line or beam elements; papers on rotating beams are also included. The determination of natural frequencies and mode shapes of rotating structures, such as turbine blades is very important in the design of turbomachines. Therefore as special subsections also blades and spindels are addressed.

\subsection{Rotors}

Topics included: finite element modelling techniques in rotating machinery; linear and nonlinear vibration analysis; modal analysis; rotor model updating; multi-body dynamic modelling; flexural behavior of rotors; torsional vibration analysis; analysis of whirl speeds; aeroelastic/aerodynamic rotorcraft analysis; vibratory rotor hub loading; effect of misalignment on rotor vibrations; rotary machines subjected to earthquake; finite elements for rotor modelling.

Types of rotor systems under consideration: flexible rotor systems; flexible rotors on flexible suspensions; flexible rotors in magnetic bearings; rotor-bearing systems; multi-bearing rotors; geared rotor-bearing systems; rotor-shaft-bearing systems; rotor-bearing with misaligned shafts; rotors supported by a spherical spiral groove bearings; rotors supported by a piecewise linear journal bearings; blade-disc-shaft systems; composite rotors.

\subsection{Discs}

The following topics are included in this subsection: dynamic modelling of discs; linear and nonlinear vibration analysis; vibration localization; prediction of forced response in time and frequency domains; modal interactions is spinning discs; flexural, torsional and axial dynamic analysis; thermally stressed spinning plates.

Types of discs analyzed: rotating isotropic/orthotropic/anisotropic discs; rotating pretwisted plates; circular discs with noncentral holes; bladed discs; mistuned bladed discs; bladed discs with friction dampers; flexible bladed disc-shaft assemblies; disc-shaft assemblies; composite discs; reinforced ceramic rotating discs.

\subsection{Shafts}

In this subcategory the following subjects are handled: dynamic modelling of rotating beams/shafts; modal analysis; linear and nonlinear vibration analysis; high-speed rotation analysis; model updating techniques; twisted rotating beams; coupled torsionallateral-axial vibration analysis; coupled torsional-flexural vibration analysis; finite elements for shaft modelling.

Rotating elements under consideration: rotating beams and shafts; Timoshenko beams; filleted shafts; D-shaped shafts; geared shaft systems; flexible links; circular plates with solid shafts; bladed disc-shaft assemblies; disc-shaft assemblies; composite beams/ shafts.

\subsection{Spindles}

Topics included: dynamic modelling of spindles; modal analysis; identification of modal parameters; vibration and deformation analyses.

Rotating elements/systems: spindles; spindle-bearing systems; lathe-spindle assembly; cutting machine tool spindles; grinding machine tool spindles; hydrostatic gas bearing spindles; air-spindles.

\subsection{Blades}

This subsection deals with topics such as: dynamic modelling of rotating blades; modal analysis; linear and nonlinear vibration analysis; deformation analysis; forced response analysis; damping considerations; vibration analysis of pre-twisted blades; aeroelastic response analysis.

The following components are included: blades; blades with flexible coupling; blades with small holes; blade arrays; composite rotor blades.

\section{Fracture mechanics and fatigue}

Rotating machinery components are prone to cracking and failure caused by creep, fatigue and their interaction. Fatigue crack growth studies are central to damage-tolerance approaches. Mathematical models of cracked rotor systems have been developed to predict the change in vibrational behavior due to crack growth. The main subject of this section are finite element, linear and nonlinear, studies of various aspects of vibration of rotating machinery with a crack. 
This section deals with finite element analysis of rotating crack models. Included are topics such as: vibration analysis; modal parameters identification; crack initiation and propagation; dynamic failure analysis; damage analysis and detection; environmental and mechanical fatigue; fretting fatigue; fatigue crack growth and propagation; creep-fatigue modelling; creep crack initiation; surface flaw behaviors; lifetime evaluation; probabilistic fracture mechanics; sensitivity analysis; stress intensity factor computations.

The following cracked components are under consideration: rotors; shafts; discs; turboalternator rotors; helicopter rotors; turbine blades; turbine rotors; compressor blades; aeroengine discs; rotor-bearing systems.

\section{Contact and contact-impact problems}

The contact in rotating systems has long been recognized as a major contributor to their failures. Developing adequate contact models and incorporating them into the dynamic finite element analysis of rotating machinery are key issues in order to understand the mechanisms and in this way to predict accurately the phenomena. Many rotors also contain components stacked and held together. When the rotor whirls, working joints are causing the friction damping which is a potential source of instability.

Types of contact and contact-impact problems that are analyzed/simulated in this section are, for example: rotor-stator contact problems; rotor-bearing contacts; shaft-hub connections; gear-shaft connections; shaftcone connections; blade-disc connections; joints of hollow shafts; shaft couplings for rotor wheels; joints of aeroengine discs; rotor-foundation interaction; frictional heating in shaft-bush system; contact analysis of turbine blades; impact behavior of rotor dynamic systems; crashworthy rotorcraft design; blast loading of discs; helicopter rotor blade-droop stop impacts.

\section{Stability analysis}

Rotors should not be working in the unstable regime. The instability is induced by fluid-solid interaction and can be seen as a spontaneous growth in whirl amplitude upon reaching some threshold speed. The sources of instability are bearings and seals, passive forces in turbines or impellers, internal friction, etc.
Vibration and dynamic stability/instability problems are the subjects of this section. The following components/systems have been analyzed by finite element methods: discs; rotating shafts; cracked shafts and rotating beams; rotating blades; turbomachinery blades; Timoshenko shafts; composite shafts; non-symmetric rotors on distributed bearings; pre-twisted rotors; rotorbearing systems. The aeroelastic stability of helicopter rotor blades is also included.

\section{Specific industrial applications}

Specific industrial applications in this last section include finite element analyses and design considerations of: compressor rotors; gas turbine rotors and blades; turbogenerator rotors; rotorcraft transmissions; helicopter rotors and blades; rotors of gyroscopes and centrifuges; bearingless helicopter rotors; rotor-fuselage systems; cam engine shaft systems; wing drive shafts; multiblade fan shaft systems; turbine blades; wind turbine blades; aircraft turbine blades; turbine blade rows; centrifugal and hydraulic pumps.

Readers interested in the finite element literature in general are referred to [3] or to the author's Internet Finite Element Book Bibliography (http://www. solid.ikp.liu.se/fe/index.html). The solutions of rotordynamic problems in general can be found in many books, for example in [4-9]. A list of references on finite element analysis of machine elements where bearings and seals are included can be found in [10], and the active vibration control is a part of the [11].

\section{Acknowledgement}

The bibliography presented is by no means complete but it gives a comprehensive representation of different finite element applications on the subjects. The author wishes to apologize for the unintentional exclusions of missing references and would appreciate receiving comments and pointers to other relevant literature for a future update.

\section{Reference}

[1] J. Mackerle, MAKEBASE, an information retrieval system in structural mechanics for main-frames and personal computers, Eng. Computations 6 (1989), 178-185 
[2] J. Mackerle, An information retrieval system for finite element and boundary element literature and software, Eng. Analysis with Boundary Elements 11 (1993), 177-187.

[3] J. Mackerle, Finite Element Methods, A Guide to Information Sources, Elsevier, Amsterdam, 1991.

[4] M. Lalanne and G. Ferraris, Rotordynamics Predictions in Engineering, 2nd edn, J. Wiley, Chichester, 1998.

[5] D. Childs, Turbomachinery Rotordynamics, J. Wiley, Chichester, 1993.

[6] F. Ehrich, Handbook on Rotordynamics, McGraw-Hill, New York, 1992.

[7] G. Genta, Vibrations of Structures and Machines, Practical Aspects, Springer-Verlag, Berlin, 1995.

[8] E. Kramer, Dynamics of Rotors and Foundations, SpringerVerlag, Berlin, 1993.

[9] C.W. Lee, Vibration Analysis of Rotors, Pergamon Press, New York, 1993.

[10] J. Mackerle, Finite element analysis of machine elements, A bibliography (1977-1997), Eng. Computations 16 (1999), in print.

[11] J. Mackerle, Smart materials and structures - a finite element approach: a bibliography (1986-1997), Modelling and Simulation in Materials Science and Eng. 6 (1998), 293-334.

\section{BIBLIOGRAPHY}

\section{Rotors and their elements}

\section{Rotors}

[1] B.O. Al-Bedoor, Dynamic model of coupled shaft torsional blade bending deformations in rotors, Computer Methods in Applied Mechanics and Engineering 169(1/2) (1999), 177190.

[2] C.A. Almeida, On the use of finite element modeling techniques to represent rotating machinery, in: 4th World Congress on Computational Mechanics, Buenos Aires, 1998, pp. 268.

[3] S. Audebert et al., Multi-bearing rotor model updating using experimental modal and response data, in: 15th International Modal Analysis Conference, Orlando, IMAC, 1997, pp. 162168.

[4] O.A. Bauchau and M. Lee, Multi-body formulation for rotorcraft dynamic analysis, in: 51st Annual Forum, American Helicopter Society, 1995, pp. 1788-1798.

[5] W.J. Chen, A note on computational rotor dynamics, J. of $\mathrm{Vi}$ bration and Acoustics, ASME 120(1) (1998), 228-233.

[6] C.G. Chien et al., Non-linear vibration analysis of the coupled textile/rotor system by finite element method, J. of Sound and Vibration 221(1) (1999), 67-84.

[7] D.S. Dancila et al., Star-shape cross-section extension-twistcoupled composite beams for rotorcraft applications, in: Annual Forum Proceedings, American Helicopter Society, 2, Washington, 1998, pp. 1044-1048.
[8] F.M.A. El-Saeidy, Finite element modeling of a rotor shaft rolling bearings system with consideration of bearing nonlinearities, J. of Vibration and Control 4(5) (1998), 541-602.

[9] H. Fukuyama and T. Someya, Dynamic analysis of a rotor system supported by a spherical spiral groove bearing, Trans. of the Japan Society of Mechanical Engineers, Ser. C 60(570) (1994), 467-475.

[10] B.J. Gaganis et al., Modal analysis of rotor on piecewise linear journal bearings under seismic excitation, J. of Vibration and Acoustics, ASME 121(2) (1999), 190-196.

[11] R. Ganguli et al., Validation of calculated vibratory rotor hub loads with experimental data, in: 53rd Annual Forum, American Helicopter Society, 2, Virginia Beach, 1997, pp. 13631372.

[12] R. Ganguli et al., Comparison of calculated vibratory rotor hub loads with experimental data, J. of the American Helicopter Society 43(4) (1998), 312-318.

[13] G. Genta and A. Tonoli, A disk finite element for the study of the flexural behaviour of rotors, in: 3rd World Congress on Computational Mechanics, Chiba, Japan, 1994, pp. A12-2.

[14] R.E. Hansford and J. Vorwald, Dynamics workshop on rotor vibratory loads, in: 52nd Annual Forum, American Helicopter Society, 1996, pp. 93-110.

[15] R.E. Hansford and J. Vorwald, Dynamics workshop on rotor vibratory loads prediction, J. of the American Helicopter Society 43(1) (1998), 76-87.

[16] T. Huang, Transfer matrix-component mode synthesis for rotordynamic analysis, in: 1996 International Gas Turbine and Aeroengine Congress and Exhibition, Burmingham, ASME, 1996, pp. GT-79.

[17] Y. Kaneko et al., Torsional vibration analysis of blade-diskshaft system by the finite element method and the transfer matrix method, Trans. of the Japan Society of Mechanical Engineers, Ser. C 61(586) (1995), 36-41.

[18] Y.A. Khulief and M.A. Mohiuddin, On the dynamic analysis of rotors using modal reduction, Finite Elements in Analysis and Design 26(1) (1997), 41-55.

[19] J. Kicinski, Nonlinear model of vibration in rotor-bearing system. Part I: Calculation algorithm, Transaction of the Institute of Fluid-Flow Machinery (100) (1996), 91-107.

[20] J. Kicinski, Nonlinear model of vibration in rotor-bearings system: calculation algorithm, Machine Dynamics Problems 15 (1996), 45-60.

[21] J. Kicinski et al., The non-linear analysis of the effect of support construction properties on the dynamic properties of multi-support rotor systems, J. of Sound and Vibration 206(4) (1997), 523-539.

[22] J. Kicinski et al., Nonlinear model of vibrations in a rotorbearings system, J. of Vibration and Control 4(5) (1998), 519540.

[23] D.M. Ku, Finite element analysis of whirl speeds for rotorbearing systems with internal damping, Mechanical Systems and Signal Processing 12(5) (1998), 599-610.

[24] C.S. Lee et al., Aerodynamic and numerical issues for coupling CFD into comprehensive rotorcraft analysis, in: $53 \mathrm{rd}$ Annual Forum, American Helicopter Society, 2, Virginia Beach, 1997, pp. 1068-1087. 
[25] M.A. Mohiuddin and Y.A. Khulief, Modal characteristics of rotors using a conical shaft finite element, Computer Methods in Applied Mechanics and Engineering 115(1/2) (1994), 125144.

[26] M.A. Mohiuddin and Y.A. Khulief, Coupled bending torsional vibration of rotors using finite element, J. of Sound and Vibration 223(2) (1999), 297-316.

[27] H.D. Nelson, Rotordynamic modeling and analysis procedures: a review, JSME International J., Ser. C 41(1) (1998), $1-12$.

[28] J.L. Nikolajsen, Effect of misalignment on rotor vibrations, in: 1996 International Gas Turbine and Aeroengine Congress and Exhibition, Burmingham, ASME, 1996, pp. GT-373.

[29] J.L. Nikolajsen, Effect of misalignment on rotor vibrations, J. of Engineering for Gas Turbines and Power 120(3) (1998), 635-640.

[30] J.L. Nikolajsen and E.A. L'Antigua, Simplified method for analyzing rotors with conical shell sections, in: 3rd Joint Conference on Engineering Systems Design and Analysis, PD 81, ASME, 1996, pp. 223-230.

[31] S. Okamoto and H. Okada, Vibration analysis of squeeze film damper approx. flexible rotor system subjected to base excitation, Trans. of the Japan Society of Mechanical Engineers, Ser. C 62 (597) (1996), 1676-1684.

[32] S. Okamoto and H. Okada, Simulations of vibration for squeeze film dampers-rotor system subjected to earthquake with vertical shock (2nd Rep., A flexible rotor system), Trans. of the Japan Society of Mechanical Engineers, Ser. C 62 (604) (1996), 4461-4468.

[33] S. Okamoto et al., Vibration analysis of a high-speed and light weight rotor system subjected to a pitching or turning motion, II: A flexible rotor system on flexible suspension, J. of Sound and Vibration 184(5) (1995), 887-906.

[34] A.V. Phan and G. Reynaud, Determination of the asynchronous load on a rotor from the measured internal forces, J. of Sound and Vibration 206(1) (1997), 15-22.

[35] T.R. Quackenbush et al., Rotor aerodynamic loads computation using a constant vorticity contour free wake model, J. of Aircraft 32(5) (1995), 911-920.

[36] A.S. Rao and A.S. Sekhar, Vibration analysis of rotorcoupling-bearing system with misaligned shafts, in: 1996 International Gas Turbine and Aeroengine Congress and Exhibition, Burmingham, ASME, 1996, pp. GT-12.

[37] B.S. Rao et al., Analysis of rotors considering distributed bearing stiffness and damping, Computers and Structures 61 (5) (1996), 951-955.

[38] A.S. Sekhar and B.S. Prabhu, Effects of coupling misalignment on vibrations of rotating machinery, J. of Sound and Vibration 185(4) (1995), 655-671.

[39] T.N. Shiau et al., Study on the dynamic characteristics of geared rotor-bearing system with hybrid method, in: International Gas Turbine and Aeroengine Congress and Exposition, Hague, ASME, 1994, pp. 94-GT-355.

[40] T.N. Shiau et al., Vibration and control of a flexible rotor in magnetic bearings using hybrid method and $\mathrm{H}$ infinite control theory, in: International Gas Turbine and Aeroengine Congress and Exposition, Hague, ASME, 1994, pp. 94-GT57.
[41] T. N. Shiau et al., Vibration and control of a flexible rotor in magnetic bearings using hybrid method and $\mathrm{H}$ infinite control theory, J. of Engineering for Gas Turbines and Power 119(1) (1997), 178-185.

[42] C.W. Spencer and S.L. Killian, Structural analysis of large titanium castings in a high-cycle, rotor-induced vibratory load environment, in: 51st Annual Forum, American Helicopter Society, 1995, pp. 1615-1626.

[43] R. Srivastava and T.S.R. Reddy, Aeroelastic analysis of ducted rotors, in: 1995 ASME International Mechanical Engineering Congress and Exposition, AD 49, ASME, 1995, pp. 1-9.

[44] E.L.B. Van de Vorst et al., Steady-state behavior of flexible rotordynamic systems with oil journal bearings, in: 1994 International Mechanical Engineering Congress and Exposition, AMD 192, ASME, 1994, pp. 107-114.

[45] E.L.B. Van de Vorst et al., Steady-state behaviour of flexible rotordynamic systems with oil journal bearings, Nonlinear Dynamics 11(3) (1996), 295-313.

[46] S.W. Wu et al., Finite element formulation of a conical beam element for rotor dynamics analysis, Transaction of the Chinese Institute of Engineers, Ser. C 18(3) (1997), 293-299.

[47] W. Yu, Prediction of periodic response of rotor dynamic systems with nonlinear supports, J. of Vibration and Acoustics, ASME 119(3) (1997), 346-353.

[48] V. Zeman and L. Kovar, Dynamical analysis of the large mechanical systems containing subsystems, Zeitschrift für Angewandte Mathematik und Mechanik 78(S2) (1998), 833-834.

Discs

[49] M. Berthillier et al., Numerical method for the prediction of bladed disk forced response, in: International Gas Turbine and Aeroengine Congress and Exposition, Hague, ASME, 1994, pp. 1-9.

[50] M. Berthillier et al., Numerical method for the prediction of bladed disk forced response, J. of Engineering for Gas Turbines and Power 119(2) (1997), 404-410.

[51] R. Bladh et al., Reduced order modeling and vibration analysis of mistuned bladed disk assemblies with shrouds, in: International Gas Turbine and Aeroengine Congress and Exhibition, Stockholm, 1998, pp. GT-484.

[52] M.P. Castanier et al., A reduced order modeling technique for mistuned bladed disks, J. of Vibration and Acoustics, ASME 119(3) (1997), 439-447.

[53] J.S. Chen and C.C. Wong, Modal interactions in a spinning disk on a floating central collar and restrained by multiple springs, J. of the Chinese Society of Mechanical Engineers 17(3) (1996), 251-259.

[54] G. Csaba, Forced response analysis in time and frequency domains of a tuned bladed disk with friction dampers, $J$. of Sound and Vibration 214(3) (1998), 395-412.

[55] G. Genta and A. Tonoli, A harmonic finite element for the analysis of flexural, torsional and axial rotordynamic behaviour of discs, J. of Sound and Vibration 196(1) (1996), 1943.

[56] A. Gupta et al., Vibration analysis of composite disks, in: 16th International Modal Analysis Conference, Santa Barbara, 1998, pp. 1540-1542. 
[57] A. Heydari et al., Boundary layers on a rotating rough disk, in: Computers in Engineering 1994, Minneapolis, ASME, 1994, pp. 775-778.

[58] F. Hild and F.A. Leckie, Fiber distribution in reinforced ceramic rotating discs, in: International Gas Turbine and Aeroengine Congress and Exposition, Houston, ASME, 1995, pp. GT-94.

[59] S.H. Hsieh and J.F. Abel, Comparison of two finite element approaches for analysis of rotating bladed-disk assemblies, J. of Sound and Vibration 182(1) (1995), 91-107.

[60] Jacquet-Richardet et al., Frequencies and modes of rotating flexible bladed disc-shaft assemblies: a global cyclic symmetry approach, J. of Sound and Vibration 191(5) (1996), 901915.

[61] R. Jain et al., Rotating anisotropic disc of uniform strength, Int. J. of Mechanical Sciences 41(6) (1999), 639-648.

[62] R. Karakuzu and O. Sayman, Elasto-plastic finite element analysis of orthotropic rotating discs with holes, Computers and Structures 51(6) (1994), 695-703.

[63] A. Karmakar and P.K. Sinha, Finite element free vibration analysis of rotating laminated composite pretwisted cantilever plates, J. of Reinforced Plastics and Composites 16(16) (1997), 1461-1491.

[64] H.R. Kim and A.A. Renshaw, Asymmetric, speed dependent tensioning of circular rotating disks, J. of Sound and Vibration 218(1) (1998), 65-80.

[65] Y. Kobayashi et al., Free vibration of a rotating disk-blade coupled system with shrouds, in: 1996 International Gas Turbine and Aeroengine Congress and Exhibition, Burmingham, ASME, 1996, pp. GT-22.

[66] M. Kohl et al., Axisymmetric substitute structures for circular disks with noncentral holes, Computers and Structures 60(6) (1996), 1047-1065.

[67] M.J. Kruse and C. Pierre, Experimental investigation of vibration localization in bladed disks, Part I. Free response, in: 1997 International Gas Turbine and Aeroengine Congress and Exposition, Orlando, ASME, 1997, pp. GT-501.

[68] D.S. Kumar et al., A modified semi-analytical approach towards the modelling of a shaft-disc system, Computers and Structures 61(1) (1996), 189-191.

[69] D.S. Kumar et al., Disc flexibility effects in rotor bearing systems, Computers and Structures 62(4) (1997), 715-719.

[70] C. Minas and S. Kodiyalam, Vibration analysis of bladed disc assemblies, Mechanics of Structures and Machines 23(3) (1995), 321-330

[71] G.S. Ottarsson, Dynamic modeling and vibration analysis of mistuned bladed disks, PhD Thesis, The University of Michigan, 1994.

[72] C.V. Ramakrishnan and G.V.V.R. Kumar, Estimation of root damping in blade disk assembly using nonlinear joint elements, in: 4th International Conference on Computational Plasticity, 2, D.R.J. Owen, ed., Pineridge Press, 1995, pp. 2237-2248.

[73] G.V. Rao et al., A finite element free vibration analysis of a thermally stressed spinning plate, Computers and Structures 59(2) (1996), 377-385.

[74] J.C. Slater and A.J. Blair, Minimizing sensitivity of bladed disks to mistuning, in: 16th International Modal Analysis Conference, Santa Barbara, 1998, pp. 284-290.
[75] T. Tomioka et al., Analysis of free vibration of rotating diskblade coupled systems by using artificial springs and orthogonal polynomials, J. of Sound and Vibration 191(1) (1996), 53-73.

[76] T. Tsuiji et al., Free vibration analysis of rotating thin twisted plates, Trans. of the Japan Society of Mechanical Engineers, Ser. C 61(592) (1995), 4575-4583.

[77] N. Tutuncu and A. Durdu, Determination of buckling speed for rotating orthotropic disk restrained at outer edge, AIAA J. 36(1) (1998), 89-93.

[78] H. Vinayak and R. Singh, Eigensolutions of annular-like elastic disks with intentionally removed or added material, $J$. of Sound and Vibration 192(4) (1996), 741-769.

[79] M.T. Yang and J.H. Griffin, Reduced order approach for the vibration of mistuned bladed disk assemblies, in: International Gas Turbine and Aeroengine Congress and Exposition, Houston, ASME, 1995, pp. GT-454.

[80] M.T. Yang and J.H. Griffin, Reduced order approach for the vibration of mistuned bladed disk assemblies, J. of Engineering for Gas Turbines and Power 119(1) (1997), 161-167.

[81] L.H. You and J.J. Zhang, Elastic-plastic stresses in a rotating solid disk, Int. J. of Mechanical Sciences 41(3) (1999), 269282.

[82] W. Zhang et al., Dynamic analysis of rotating bladeddisk/shaft coupled system, in: 3rd World Congress on Computational Mechanics, Chiba, Japan, 1994, pp. A8-2.

[83] W. Zhang et al., Finite element approach to the analysis of rotating bladed-disk assemblies coupled with flexible shaft, in: International Gas Turbine and Aeroengine Congress and Exposition, Hague, ASME, 1994, pp. 1-8.

\section{Shafts}

[84] B.O. Al-Bedoor and Y.A. Khulief, Finite element dynamic modeling of a translating and rotating flexible link, Computer Methods in Applied Mechanics and Engineering 131(1/2) (1996), 173-189.

[85] T. Allen et al., Robust engineering using numerical methods: application to the design of D-shaped shafts, SAE Special Publication 1347(1998), 105-115.

[86] A. Bazoune et al., Further results for modal characteristics of rotating tapered Timoshenko beams, J. of Sound and Vibration 219(1) (1999), 157-174.

[87] J.J. Epps and R. Chandra, Natural frequencies of rotating composite beams with tip sweep, J. of the American Helicopter Society 41(1) (1996), 29-36.

[88] B. Fallahi and S.H.Y. Lai, An improved numerical scheme for characterizing dynamic behavior of high-speed rotating elastic beam structures, Computers and Structures 50(6) (1994), 749-755.

[89] A. Girard et al., Model updating by energy approach for rotating shafts, in: 15th International Modal Analysis Conference, Orlando, IMAC, 1997, pp. 1419-1425.

[90] I. Hayashi et al., The theoretical modal analysis of a circular plate with a solid shaft, J. of Sound and Vibration 173(5) (1994), 633-655. 
[91] M. Iura and S.N. Atluri, Dynamic analysis of planar flexible beams with finite rotations by using inertial and rotating frames, Computers and Structures 55(3) (1995), 453-462.

[92] Jacquet-Richardet et al., Frequencies and modes of rotating flexible bladed disc-shaft assemblies: a global cyclic symmetry approach, J. of Sound and Vibration 191(5) (1996), 901915.

[93] T.Y. Kam and C.K. Liu, Stiffness identification of laminated composite shafts, Int. J. of Mechanical Sciences 40(9) (1998), 927-936.

[94] H. Kang et al., Theoretical modal analysis of a circular plate with a solid shaft and a solid cylinder, Trans. of the Japan Society of Mechanical Engineers, Ser. C 61(583) (1995), 894 901.

[95] J. Kolenda, Simplified description of propeller-induced and kinematically excited shafting transversal vibrations, Marine Technology Transactions 6(1995), 197-218.

[96] D.S. Kumar et al., A modified semi-analytical approach towards the modelling of a shaft-disc system, Computers and Structures 61(1) (1996), 189-191.

[97] S.H.Y. Lai, Dynamic modeling and control of a rotating piezobonded beam-mass system, Mechanics Research Communications 21(2) (1994), 181-188.

[98] S.H.Y. Lai, Nonlinear finite element modeling of a high speed rotating Timoshenko beam structure, Int. J. of Mechanical Sciences 36(9) (1994), 849-861.

[99] S.H.Y. Lai, Geometrically nonlinear transient analysis of a rotating beam structure carrying a static payload, Mechanics $R e$ search Communications 21(5) (1994), 473-482.

[100] E. Lantto, Finite element model for elastic rotating shafts, Acta Polytechnica Scandinavica (88) (1997), 2-73.

[101] Z. Luo et al., Coupled torsional-lateral-axial vibration analysis of a geared shaft system using substructure synthesis, Mechanism and Machine Theory 31(3) (1996), 345-352.

[102] C.X. Mao and Q.H. Qin, Coupled torsional-flexural vibration of shaft systems in mechanical engineering, II: FE-TM impedance coupling method, Computers and Structures 58(4) (1996), 845-849.

[103] K.L. Napolitano et al., Cocured extension-twist coupled damped composite torsion shaft, in: 39th Structures, Structural Dynamics and Material Conference and Exhibition, Long Beach, 4, 1998, pp. 3149-3159.

[104] D.C.D. Oguamanam and G.R. Heppler, Effect of rotating speed on the flexural vibration of a Timoshenko beam, in: 13th IEEE International Conference on Robotics and Automation, Minneapolis, 1996, pp. 2438-2443.

[105] Q.H. Qin and C.X. Mao, Coupled torsional-flexural vibration of shaft systems in mechanical engineering, I: Finite element model, Computers and Structures 58(4) (1996), 835-843.

[106] P.P. Sheu et al., Modeling and analysis of the intermediate shaft between two universal joints, J. of Vibration and Acoustics, ASME 118(1) (1996), 88-99.

[107] A.D. Stemple et al., Vibration analysis of rotating composite beams using a finite element model with warping degrees of freedom, Computational Mechanics 16(4) (1995), 258-265.

[108] G. Surace et al., A finite element formulation for modal analysis of twisted rotating elastic beams, Meccanica 32(4) (1997), $377-380$.
[109] S.M. Tipton et al., Updated stress concentration factors for filleted shafts in bending and tension, J. of Mechanical Design, ASME 118(3) (1996), 321-327.

[110] H.L. Wettergren, The influence of imperfections on the eigenfrequencies of a rotating composite shaft, J. of Sound and Vibration 204(1) (1997), 99-116.

[111] Q.Z. Xiao et al., An improved hybrid-stress element approach to torsion of shafts, Computers and Structures 71(5) (1999), 535-563.

[112] J. Yu and A. Craggs, 3-D solid finite element modeling of rotating shafts, in: 15th International Modal Analysis Conference, Orlando, IMAC, 1997, pp. 1488-1494.

[113] W. Zhang et al., Finite element approach to the analysis of rotating bladed-disk assemblies coupled with flexible shaft, in: International Gas Turbine and Aeroengine Congress and Exposition, Hague, ASME, 1994, pp. 1-8.

\section{Spindles}

[114] J.K. Choi and D.G. Lee, Characteristics of a spindle bearing system with a gear located on the bearing span, International J. of Machine Tools and Manufacture 37(2) (1997), 171-181.

[115] Z. Han et al., Identification method of the modal parameters of lathe spindle assembly, in: Structural Dynamics and Vibration, PD 64, London, ASME, 1994, pp. 109-113.

[116] U. Heisel et al., Modular structure of FE model for the calculation of cutting machine tool spindles, Konstruktion 47(11) (1995), 358-362.

[117] Y. Inada et al., Development of wheel spindle for ultra-high speed surface grinding machine-studies of ultra-high speed grinding (1st Rep.), J. of the Japan Society of Precision Engineering 62(4) (1996), 569-573.

[118] W.R. Wang and C.N. Chang, Dynamic analysis and design of a machine tool spindle-bearing system, J. of Vibration and Acoustics, ASME 116(3) (1994), 280-285.

[119] B.H. Wilson and J. Gao, Applications of continuum-based models of machine tool spindle drives, in: Proc. of the American Control Conf., Baltimore, 1994, pp. 3318-3322.

[120] H. Yamamoto et al., Vibration analysis of hydrostatic gas bearing spindle considering the elastic deformation of rotor, Trans. of the Japan Society of Mechanical Engineers, Ser. C 62(603) (1996), 4294-4301.

[121] K. Yokoyama, Analysis of deformation of air-spindle due to centrifugal force, J. of the Japan Society of Precision Engineering 64(1) (1998), 137-141.

\section{Blades}

[122] B.O. Al-Bedoor, Vibrations of a rotating blade with flexible coupling in the drive system, in: ASME/JSME Joint Pressure Vessels and Piping Conference, PVP 368, ASME, 1998, pp. 69-76.

[123] M. Berthillier et al., Blades forced response analysis with friction dampers, J. of Vibration and Acoustics, ASME 120(2) (1998), 468-474. 
[124] C.E.S. Cesnik and D.H. Hodges, VABS: a new concept for composite rotor blade cross-sectional modeling, in: 52nd Annual Forum, American Helicopter Society, 1995, pp. 16271640.

[125] J.J. Chen and C.H. Menq, Prediction of the resonant response of frictionally constrained blade systems using constrained mode shapes, in: International Gas Turbine and Aeroengine Congress and Exhibition, Stockholm, 1998, pp. GT-548.

[126] Y.C. Fan et al., Experimental study on vibration of a rotating blade, J. of Engineering for Gas Turbines and Power 116(3) (1994), 672-677.

[127] J. Frischbier et al., Blade vibrations of a high speed compressor blisk-rotor numerical resonance tuning and optical measurements, in: 1996 International Gas Turbine and Aeroengine Congress and Exhibition, Burmingham, ASME, 1996, pp. GT-24.

[128] C. Gao et al., Calculation and analysis of three-dimensional long blade vibration characteristics, J. of Engineering for Thermal Energy and Power 13(5) (1998), 348-350.

[129] G. Genta and A. Tonoli, Harmonic finite element for the analysis of flexural, torsional and axial rotordynamic behavior of blade arrays, J. of Sound and Vibration 207(5) (1997), 693720 .

[130] Jacquet-Richardet and P. Swider, Influence of fibre orientation on the dynamic behaviour of rotating laminated composite blades, Communications in Numerical Methods in Engineering 13(10) (1997), 815-824.

[131] S.N. Jung and S.J. Kim, Aeroelastic response of composite rotor blades considering transverse shear and structural damping, AIAA J. 32(4) (1994), 820-827.

[132] M.J. Jweeg and S.Z. Said, Effect of rotational and geometric stiffness matrices on dynamic stresses and deformations of rotating blades, $J$. of the Institution of Engineers (India) Mechanical Engineering Div. 76(1995), 29-38.

[133] G.L. Liu, Generalized untwist problem of rotating blades: a coupled aeroelastic formulation, in: International Gas Turbine and Aeroengine Congress and Exposition, Hague, ASME, 1994, pp. 1-6.

[134] S.M. Nabi and N. Ganesan, Comparison of beam and plate theories for free vibrations of metal matrix composite pretwisted blades, J. of Sound and Vibration 189(2) (1996), 149160.

[135] F.K. Straub et al., Advanced finite element modeling of rotor blade aeroelasticity, J. of the American Helicopter Society 39(2) (1994), 56-68.

[136] I.S. Vorobev et al., Numerical investigation of blade packet vibrations, in: ASME Asia Congress and Exhibition, Singapore, ASME, 1997, pp. AA-20.

[137] T.H. Young and G.T. Liou, Dynamic response of spinning blades subjected to gyroscopic motion, J. of Vibration and Acoustics, ASME 116(1) (1994), 6-15.

[138] J. Zhang et al., Modal analysis of blades with densely distributed small holes, in: International Gas Turbine and Aeroengine Congress and Exposition, Hague, ASME, 1994, pp. $1-4$.

\section{Fracture mechanics and fatigue}

[139] I. Ballo, Non-linear effects of vibration of a continuous transverse cracked slender shaft, J. of Sound and Vibration 217(2) (1998), 321-333.

[140] G. Belloni et al., Fretting fatigue conditions for two types of turboalternator rotor, Proceedings of the Institution of Mechanical Engineers, Part C 212(6) (1998), 429-440.

[141] V. Bordi et al., A finite element analysis of crack initiation and propagation in a notched disk submitted to rolling contact fatigue, J. of Tribology, ASME 120(3) (1998), 436-441.

[142] C. Caprile et al., Environmental and mechanical fatigue of wind turbine blades made of composite materials, J. of Reinforced Plastics and Composites 15(7) (1996), 673-691.

[143] A. Carnero et al., Numerical evaluation of the life consume in a $75 \mathrm{MW}$ steam turbine rotor, in: 59th Annual American Power Conference, (59-2), Chicago, 1997, pp. 611-617.

[144] A. Carpinteri et al., Surface flaws in cylindrical shafts under rotary bending, Fatigue and Fracture of Engineering Materials and Structures 21(9) (1998), 1027-1035.

[145] A. De-Andres et al., Elastoplastic finite element analysis of three-dimensional fatigue crack growth in aluminum shafts subjected to axial loading, International J. of Solids and Structures 36(15) (1999), 2231-2258.

[146] M.O. Dedekind, Implementation of creep-fatigue model into finite element code to assess cooled turbine blade, International J. of Pressure Vessels and Piping 59(1/3) (1994), 1321.

[147] G. Dhondt and M. Kohl, The effect of the geometry and the load level on the dynamic failure of rotating disks, International J. of Solids and Structures 36(6) (1999), 789-812.

[148] B.O. Dirr et al., Detection and simulation of small transverse cracks in rotating shafts, Archive of Applied Mechanics 64(3) (1994), 206-222.

[149] T.H. Fronk et al., Analyses and design tool for the prediction of structural failure of current and future composite wind turbine blades, in: Energy-Source Technical Conference and Exhibition, SED 16, ASME, 1995, p. 9.

[150] R. Ganguli et al., Formulation of a rotor-system damage detection methodology, in: 36th Structures, Structural Dynamics and Material Conference, New Orleans, AIAA, 1995, pp. $645-668$.

[151] R. Ganguli et al., Formulation of a helicopter rotor system damage detection methodology, J. of the American Helicopter Society 41(4) (1996), 302-312.

[152] R. Ganguli et al., Detection of helicopter rotor system simulated faults using neural networks, J. of the American Helicopter Society 42(2) (1997), 161-171.

[153] R. Ganguli et al., Simulation of helicopter rotor-system structural damage, blade mistracking, friction, and freeplay, J. of Aircraft 35(4) (1998), 591-597.

[154] J. Granacher et al., Finite element calculation of creep crack initiation on an IP-turbine rotor using the $\mathrm{C}^{*}$-parameter, $M a$ terials at High Temperatures 15(3/4) (1998), 331-335.

[155] L. Hamidi et al., Modal parameters for cracked rotors: models and comparisons, J. of Sound and Vibration 175(2) (1994), 265-278. 
[156] J.K. Hepworth et al., Life assessment of gas turbine blades and vanes, in: 1997 International Gas Turbine and Aeroengine Congress and Exposition, Orlando, ASME, 1997, pp. GT-446.

[157] B.J. Hsieh et al., Transient analysis of a flywheel battery containment during a full rotor burst event, in: ASME/JSME Joint Pressure Vessels and Piping Conference, PVP 370, ASME, 1998, pp. 101-106.

[158] M. Ichimonji et al., Dynamics of a rotor system with a slant crack under torsional vibration, in: 1994 International Mechanical Engineering Congress and Exposition, AMD 192, ASME, 1994, pp. 81-90.

[159] A.S. Khan and T.K. Paul, A centrally cracked thin circular disk, Part II: Mixed mode fatigue crack propagation, International J. of Plasticity 14(12) (1998), 1241-1264.

[160] J.S. Kiddy and D.J. Pines, Damage detection of main rotor faults using a sensitivity-based approach, Proceedings of the SPIE 3041 (1997), 611-618.

[161] R. Kieselbach and R. Primas, Analysis of fretting fatigue failure, in: Contact Mechanics II: Computational Techniques, CMP, 1995, pp. 393-400.

[162] R.A. King et al., Fatigue cracking of the generator rotor damper bars: Jocassee pumped storage station, in: 59th Annual American Power Conference, Chicago, 1997, pp. 299304.

[163] Y. Kogo et al., Spin burst test of carbon-carbon composite disk, J. of Composite Materials 32 (11) (1998), 1016-1035.

[164] J.A. Kubiak et al., Identification of damage cause in a first row gas turbine blade, in: Cogen-Turbo Power Conference, Vienna, ASME, 1995, pp. CTP-81.

[165] T. Leon-Salamanca et al., Independent life extension of a steam turbine rotor, in: 1996 International Joint Power Generation Conference, PWR 30, ASME, 1996, pp. 611-619.

[166] Y.J. Li and T. Zimmerman, Numerical evaluation of the rotating crack model, Computers and Structures 69(4) (1998), 487-497.

[167] J. Mao et al., Damage tolerance analysis of compressor blade, in: International Gas Turbine and Aeroengine Congress and Exposition, Hague, ASME, 1994, pp. 1-4.

[168] J.R. McCracken, Risk assessment method for LP disk attachments with stress corrosion cracking, in: Power-Generation Proceed., Dallas, 1998, pp. 210.

[169] J.R. McCracken and W.R. Brose, Risk assessment method for LP disc attachments with stress corrosion cracking, in: International Joint Power Generation Conference, Denver, PWR 32, ASME, 1997, pp. 383-390.

[170] H.R. Millwater et al., Application of advanced probabilistic fracture mechanics to life evaluation of turbine rotor blade attachments, in: International Gas Turbine and Aeroengine Congress and Exposition, Houston, ASME, 1995, pp. GT214.

[171] H.R. Millwater et al., Application of advanced probabilistic fracture mechanics of life evaluation of turbine rotor blade attachments, J. of Engineering for Gas Turbines and Power 118(2) (1996), 394-398.

[172] M.A. Mohiuddin and Y.A. Khulief, Modal characteristics of cracked rotors using a conical shaft finite element, Computer Methods in Applied Mechanics and Engineering 162(1/4) (1998), 223-247.
[173] S. Neogy and V. Ramamurti, Effect of partial depth cracks on the natural frequency of twisted blades: a 3-D finite element analysis, J. of Sound and Vibration 205(1) (1997), 33-55.

[174] V. Omprakash et al., Life extension strategies of cracked disk attachment for low pressure steam turbines, in: 1994 International Joint Power Generation Conference, PWR 26, ASME, 1994, pp. 159-164.

[175] C.A. Papadopoulos, Torsional vibrations of rotors with transverse surface cracks, Computers and Structures 51(6) (1994), 713-718.

[176] P. Papanikos and S.A. Meguid, Theoretical and experimental studies of fretting-initiated fatigue failure of aeroengine compressed discs, Fatigue and Fracture of Engineering Materials and Structures 17(5) (1994), 539-550.

[177] T.K. Paul, Stresses in a thin centrally cracked circular disk, Engineering Fracture Mechanics 52(1) (1995), 139-153.

[178] T.K. Paul and A.S. Khan, A centrally cracked thin circular disk, Part I: 3D elastic-plastic finite element analysis, International J. of Plasticity 14(12) (1998), 1209-1239.

[179] R.W. Park, Crack detection, localization and estimation of the intensity in a turbo rotor, in: 1996 ASME Turbo Asia Conference, Jakarta, 1996, pp. 1-7.

[180] O. Repetski and K. Zainchkovski, Sensitivity analysis for life estimation of turbine blades, in: ASME Asia Congress and Exhibition, Singapore, ASME, 1997, pp. AA-136.

[181] S. Sarkar and S.N. Atluri, Effects of multiple blade interaction on the containment of blade fragments during a rotor failure, Finite Elements in Analysis and Design 23(2/4) (1996), 211223.

[182] S. Sarkar and S.N. Atluri, Finite element analysis of rotor fragment impact on containment structures, Computer Modeling and Simulation in Engineering 1(3) (1996), 391-427.

[183] A. Sedmak and S. Sedmak, Critical crack assessment procedure for high pressure steam turbine rotors, Fatigue and Fracture of Engineering Materials and Structures 18(9) (1995), 923-934.

[184] A.S. Sekhar, Vibration characteristics of a cracked rotor with two open cracks, J. of Sound and Vibration 223(4) (1999), 497-512.

[185] A.S. Sekhar and B.S. Prabhu, Vibration and stress fluctuation in cracked shafts, J. of Sound and Vibration 169(5) (1994), 655-667.

[186] A.S. Sekhar and A.S. Rao, Crack versus misalignment in rotor-coupling bearing system, Machine Vibration 5(3) (1996), 179-188.

[187] A.S. Sekhar et al., Dynamic analysis of a rotor system considering a slant crack in the shaft, $J$. of Sound and Vibration 208(3) (1997), 457-474.

[188] R. Sheehan and J.H. Bulloch, 60MW high pressure turbine rotor brittle fracture analysis and remanent life investigation, J. of Materials Processing Technology 56(1/4) (1996), 521530.

[189] M. Shikida et al., Fatigue crack propagation for cast iron rotating disk, JSME International J., Ser. A 38(1) (1995), 104110.

[190] M. Shirmohamadi and V. Wang, Creep crack growth and remaining life for the blade-fit area of a high pressure turbine rotor, in: 1996 International Joint Power Generation Conference, PWR 30, ASME, 1996, pp. 517-520. 
[191] M. C. Staddon et al., Analysis and resolution of a fatigue failure of a low pressure turbine blade caused by the excitation of a bladed disc mode of vibration, in: 1997 International Gas Turbine and Aeroengine Congress and Exposition, Orlando, ASME, 1997, pp. GT-359.

[192] T.C. Tsai and Y.Z. Wang, Vibration of a rotor with a transverse open crack, in: Proceedings of the National Science Council, A 22(3), Republica China, 1998, pp. 372-384.

[193] R.L. Wilson and S.A. Meguid, On the determination of mixed mode stress intensity factors of an angled crack in a disc using FEM, Finite Elements in Analysis and Design 18(4) (1995), 433-448.

[194] Y. Yamauchi et al., Evaluation of dynamic energy release rate for center-notched disk under mixed-mode loading, Trans. of the Japan Society of Mechanical Engineers, Ser. A 63(616) (1997), 2586-2591.

[195] T. Yang and S.A. Chen, Modeling and simulation of transverse cracks for rotor-bearing systems, in: 1996 ASME Turbo Asia Conference, Jakarta, 1996, pp. 1-5.

\section{Contact and contact-impact problems}

[196] V. Bordi et al., A finite element analysis of crack initiation and propagation in a notched disk submitted to rolling contact fatigue, J. of Tribology, ASME 120(3) (1998), 436-441.

[197] P.F. Cavalcante and K.L. Cavalca, Method to analyze the interaction between rotor-foundation systems, in: 16th International Modal Analysis Conference, Santa Barbara, 1998, pp. 775-781.

[198] S.L. Chen and M. Geradin, Finite element simulation of nonlinear transient response due to rotor-stator contact, Engineering Computations 14(6) (1997), 591-603.

[199] D.C. Fleming and A.J. Vizzini, Off-axis energy absorption characterization of composites for crashworthy rotorcraft design, J. of the American Helicopter Society 41(3) (1996), 239246.

[200] M.K. Ghosh and D.E. Brewe, Temperature distribution and thermal distortion due to frictional heating in a dry shaft-bush tribosystem using the finite element method, Int. J. of Mechanical Sciences 37(9) (1995), 1021-1034.

[201] M.K. Hagigat, Influence of non classical friction on the rubbing and impact behavior of rotor dynamic systems, $\mathrm{PhD}$. Thesis, Case Western Reserve University, 1994.

[202] A. Karmakar and P.K. Sinha, Finite element transient dynamic analysis of laminated composite. Pretwisted rotating plates subjected to impact, International J. of Crashworthiness 3(4) (1998), 379-391.

[203] M. Kawawaki et al., Elastoplastic finite element stress analysis and strength evaluation of adhesive lap joints of hollow shafts subjected to tensile loads, J. of Adhesion Science and Technology 12(9) (1998), 907-922.

[204] M. Kawawaki et al., Elastoplastic FEM stress analysis and strength evaluation of adhesive tapered lap joint of hollow shafts subjected to tensile loads, in: 1998 ASME International Mechanical Engineering Congress and Exposition, DE 100, ASME, 1998, pp. 77-84.
[205] J.A. Keller and E.C. Smith, Experimental and theoretical correlation of helicopter rotor blade-droop stop impacts, J. of Aircraft 36(2) (1999), 443-450.

[206] J.A. Keller et al., Experimental/theoretical correlation of analysis for helicopter rotor blade/droop stop impacts, in: 38th Structures, Structural Dynamics and Material Conference, Kissimmee, AIAA, 1997, pp. 345-357.

[207] A. Kieser, Design of shaft-hub connections with adjusting springs and plastic hubs, Konstruktion 48(9) (1996), 275-281.

[208] W.T. Kim and D.G. Lee, Torque transmission capabilities of adhesively bonded tubular lap joints for composite drive shafts, Composite Structures 30(2) (1995), 229-240.

[209] T. Kiss et al., New shaft coupling design for a high-speed rotor wheel, in: 1995 ASME Design Engineering and Technology Conference, DE 83, ASME, 1995, pp. 55-60.

[210] T. Maeno and D.B. Bogy, Effect of the rotor/stator interface condition including contact type, geometry, and material on the performance of ultrasonic motor, J. of Tribology, ASME 116(4) (1994), 726-732.

[211] M. Mase et al., Study on the contact analysis technology and optimal figure design of the root and groove for steam turbine long blades, in: 5th International Conference on Computer Aided Optimal Design of Structures, Rome, CMP, 1997, pp. 489-498.

[212] S.A. Meguid et al., Theoretical and experimental studies of structural integrity of dovetail joints in aeroengine discs, $J$. of Materials Processing Technology 56(1/4) (1996), 668-677.

[213] C.W. Mousseau and G.M. Hulbert, The dynamic response of spindle forces produced by a tire impacting large obstacle in a plane, J. of Sound and Vibration 195(5) (1996), 775-796.

[214] C.W. Mousseau and G.M. Hulbert, An efficient tire model for the analysis of spindle forces produced by a tire impacting large obstacles, Computer Methods in Applied Mechanics and Engineering 135(1/2) (1996), 15-34.

[215] K. Nonami and H.Q. Tian, Sliding mode control of flexible rotor-magnetic bearing systems using robust reduced-order VSS observer, Trans. of the Japan Society of Mechanical Engineers, Ser. C 60(571) (1994), 897-905.

[216] N. Okamoto et al., Finite element and experimental studies of creep at the interface of press fitted gears-shafts connections, J. of Mechanical Design, ASME 118(4) (1996), 568-572.

[217] N. Okamoto et al., Creep in connections between gears and shafts, Trans. of the Japan Society of Mechanical Engineers, Ser. A 62(598) (1996), 1419-1424.

[218] P. Papanikos et al., Three-dimensional nonlinear finite element analysis of dovetail joints in aeroengine discs, Finite Elements in Analysis and Design 29(3/4) (1998), 173-186.

[219] M.N. Raftenberg, Close-in blast loading of a steel disc; sensitivity to steel strength modeling, International J. of Impact Engineering 20(6/10) (1997), 651-662.

[220] L. Rubbelke and H. Schafer, The influence of shaft-coneconnections on the behavior of high-speed rotor systems, Konstruktion 46(6) (1994), 235-236.

[221] T. Sawa and M. Aoki, Elastoplastic FEM stress analysis and strength of adhesive butt joints of dissimilar hollow shafts subjected to external bending moments, Trans. of the Japan Society of Mechanical Engineers, Ser. A 62(593) (1996), 168174 
[222] T. Sawa et al., Elastoplastic finite element analysis and strength evaluation of adhesive butt joints of dissimilar hollow shafts subjected to external bending moment, in: 1995 ASME International Mechanical Engineering Congress and Exposition, DE 87, ASME, 1995, pp. 35-40.

[223] T. Sawa et al., Elastoplastic finite element analysis and strength evaluation of adhesive butt joints of similar and dissimilar hollow shafts subjected to bending, J. of Adhesion 61(1/4) (1997), 55-69.

[224] L. Shen et al., Study on mechanical properties of adhesivebonded shrink fit cemented shaft to collar connections, Weld World 35(5) (1995), 341-344.

[225] S. Srivastav et al., 3D modeling of imperfect contact conditions between turbine blades and disk, in: 1994 International Joint Power Generation Conference, PWR 26, ASME, 1994, pp. 197-204.

[226] M. Tanabe and Q. Gao, Contact-impact analysis of a geared rotor system coupled with rotational and lateral vibrations, in: 4th World Congress on Computational Mechanics, Buenos Aires, 1998, pp. 247.

[227] G. Von Esebeck et al., Investigation on ceramic-metal joints for shaft-hub connections in gas turbines, J. of Engineering for Gas Turbines and Power 118(3) (1996), 626-631.

[228] M. Weck et al., Design of adhesive-bonded shrink fittings in gear and shaft connections, Konstruktion 48(4) (1996), 59-64.

[229] B.D. Yang and C.H. Menq, Characterization of contact kinematics and application to the design of wedge dampers in turbomachinery blading: Part 2 - Prediction of forced response, J. of Engineering for Gas Turbines and Power 120(2) (1998), $418-423$.

[230] G. Zboinski, Physical and geometrical non-linearities in contact problems of elastic turbine blade attachments, Proceedings of the Institution of Mechanical Engineers, Part C 209(4) (1995), 273-286.

\section{Stability analysis}

[231] A.M. Awruch and C.F. Ehlers, Vibration and dynamic instability analysis of turbomachinery blades and airfoils, J. of the Brazilian Society of Mechanical Sciences 19(1) (1997), 3047.

[232] J.S. Chen and C.C. Wong, Vibration and stability of a spinning disk in contact with evenly-spaced stationary load systems, J. of Vibration and Acoustics, ASME 120(1) (1998), 301-302.

[233] L.W. Chen and H.K. Chen, Whirl speeds and stability of rotating shaft subjected to end loads, AIAA J. 33(9) (1995), 15691573.

[234] L.W. Chen and H.K. Chen, Stability analyses of a cracked shaft subjected to the end load, J. of Sound and Vibration 188(4) (1995), 497-513

[235] L.W. Chen and W.K. Peng, Dynamic stability of rotating blades with geometric non-linearity, J. of Sound and Vibration 187(3) (1995), 421-433.

[236] L.W. Chen and W.K. Peng, Stability analyses of a Timoshenko shaft with dissimilar lateral moments of inertia, J. of Sound and Vibration 207(1) (1997), 33-46.
[237] L.W. Chen and W.K. Peng, Stability behavior of rotating composite shafts under axial compressive loads, Composite Structures 41(3/4) (1998), 253-263.

[238] L.W. Chen and G.S. Shen, Dynamic stability of cracked rotating beams of general orthotropy, Composite Structures 37(2) (1997), 165-172.

[239] W.J. Chen, Instability threshold and stability boundaries of rotor-bearing systems, Structural Dynamics and Vibration, PD 64, London, ASME, 1994, pp. 211-218.

[240] W.J. Chen, Instability threshold and stability boundaries of rotor-bearing systems, J. of Engineering for Gas Turbines and Power 118(1) (1996), 115-121.

[241] M.H. Cho and I. Lee, Aeroelastic stability of hingeless rotor blade in hover using large deflection theory, AIAA J. 32(7) (1994), 1472-1477.

[242] O. De Santiago et al., Imbalance response of a rotor supported on open-ends integral squeeze film dampers, in: International Gas Turbine and Aeroengine Congress and Exhibition, Stockholm, 1998, pp. GT-6.

[243] L. Forrai, Stability analysis of a symmetrical rotor-bearing systems with internal damping using finite element method, in: 1996 International Gas Turbine and Aeroengine Congress and Exhibition, Burmingham, ASME, 1996, pp. GT-407.

[244] S.N. Jung and S.J. Kim, Effect of transverse shear on aeroelastic stability of a composite rotor blade, AIAA J. 33(8) (1995), 1541-1543.

[245] S.N. Jung et al., Aeroelastic stability analysis of hingeless rotor blade with composite flexures, in: 38th Structures, Structural Dynamics and Material Conference, Kissimmee, AIAA, 1997, pp. 897-905.

[246] Y. Kang et al., A modified influence coefficient method for balancing unsymmetrical rotor-bearing systems, J. of Sound and Vibration 194(2) (1996), 199-218.

[247] Y. Kang et al., Development and modification of a unified balancing method for unsymmetrical rotor-bearing systems, J. of Sound and Vibration 199(3) (1997), 349-368.

[248] G. Kawiecki and N.T. Sivaneri, Bilinear formulation applied to the response and stability of helicopter rotor blade, AIAA J. 32(10) (1994), 2036-2043.

[249] D.M. Ku and L.W. Chen, Stability and whirl speeds of rotating shaft under axial loads, Modal Analysis 9(2) (1994), 111-123.

[250] D. Lee and A.M. Waas, Stability analysis of a rotating multilayer annular plate with a stationary frictional follower load, Int. J. of Mechanical Sciences 39(10) (1997), 1117-1138.

[251] J.E. Mottershead and S.N. Chan, Flutter instability of circular discs with frictional follower loads, J. of Vibration and Acoustics, ASME 117(1) (1995), 161-163.

[252] R.A. Ormiston et al., Application of 2GCHAS to the investigation of aeromechanical stability of hingeless and bearingless rotor helicopters, in: 51st Annual Forum, American Helicopter Society, 1995, pp. 1132-1142.

[253] A. Riekstins, Computational buckling analysis of wind turbine blades, in: 9th Nordic Seminar on Computational Mechanics, Lyngby, Denmark, 1996, pp. 157-160.

[254] A.S. Sekhar and B.S. Prabhu, Unbalance response of rotors considering the distributed bearing stiffness and damping, in: International Gas Turbine and Aeroengine Congress and Exposition, Hague, ASME, 1994, pp. 1-6. 
[255] X. Shang and D.H. Hodges, Aeroelastic stability of composite rotor blades in hover, in: 36th Structures, Structural Dynamics and Material Conference, New Orleans, AIAA, 1995, pp. 2602-2610.

[256] A.G. Taylor and A. Craggs, A finite element model for a flexible non-symmetric rotor on distributed bearing: a stability study, J. of Sound and Vibration 173(1) (1994), 1-21.

[257] A.G. Taylor and A. Craggs, The effect of damping on the stability of a finite element model of a flexible non-axisymmetric rotor on tilting pad bearings, J. of Sound and Vibration 185(5) (1995), 809-825.

[258] R. Turaga et al., Stability analysis of a rigid rotor supported on hydrodynamic journal bearings with rough surfaces using the stochastic finite element method, Proceedings of the Institution of Mechanical Engineers, Part J 212(2) (1998), 121130.

[259] K.D. Wang and R.S. Amano, Turbulent instability prediction in low-pressure last stage steam turbine blades, in: 1998 ASME International Mechanical Engineering Congress and Exposition, HTD 361-1, ASME, 1998, pp. 109-116.

[260] A.C. Wijeyewickrema and L.M. Keer, Critical speeds and buckling loads of a pre-twisted rotor, J. of Sound and Vibration 179(1) (1995), 109-129.

[261] B. Yardimoglu and M. Sabuncu, Dynamic stability of discs with variable thickness and restrained elastically at the inner edge, in: Design: Analysis, Synthesis and Applications, PD 64, London, ASME, 1994, pp. 69-76.

[262] K.A. Yuan et al., Aeroelastic stability, response and loads of swept tip composite rotor blades in forward flight, in: 35th Structures, Structural Dynamics and Material Conference, AIAA, 1994, pp. 23-42.

\section{Specific industrial applications}

[263] S. Aksoy et al., Structural evaluation and testing of swept compressor rotor, J. of Engineering for Gas Turbines and Power 116(1) (1994), 217-222.

[264] B.M. Antkowiak and F.C. Nelson, Rotordynamic modeling of an actively controlled magnetic bearing gas turbine engine, in: 1997 International Gas Turbine and Aeroengine Congress and Exposition, Orlando, ASME, 1997, pp. GT-13.

[265] B.M. Antkowiak and F.C. Nelson, Rotordynamic modeling of an actively controlled magnetic bearing gas turbine engine, J. of Engineering for Gas Turbines and Power 120(3) (1998), 621-625.

[266] A. F. Avila, Integrated micro/macro approach for structural analysis of laminate composites with applications to turbine blades, in: 1997 ASME International Mechanical Engineering Congress and Exposition, PVP 369, ASME, 1997, pp. 347354.

[267] M.E. Bechly and P.D. Clausen, Structural design of a composite wind turbine blade using finite element analysis, Computers and Structures 63(3) (1997), 639-646.

[268] E.M. Belo and F.D. Marques, Analysis and vibration control of a helicopter rotor blade, in: International Conference CONTROL '94, Coventry, IEE, (389), 1994, pp. 1290-1295.
[269] M.M. Bhat et al., Studies on the determination of natural frequencies of industrial turbine blades, J. of Sound and Vibration 196(5) (1996), 681-703.

[270] A.I. Borovkov et al., 2D, 2.5D, 3D stress finite element analysis of high speed heterogeneous anisotropic rotors of gyroscopes and ultracentrifuges, Zeitschrift für Angewandte Mathematik und Mechanik 76(S5) (1996), 63-64.

[271] M.A. Caponero et al., Structural analysis of an aircraft turbine blade prototype by use of holographic interferometry, Proceedings of the SPIE 2004, 1994, pp. 150-161.

[272] M.A. Caponero et al., Modal analysis by holographic interferometry of a turbine blade for aircraft engines, Proceedings of the SPIE 2342, 1994, pp. 297-303.

[273] A. Carnero et al., Analysis of improved and original designs of a 16 inch long penultimate stage turbine blade, in: 56th Annual American Power Conference, Chicago, 1994, pp. 14861492.

[274] H.W.D. Chiang and M.H. Chung, Cyclic symmetry analysis for turbomachine blade flutter, in: International Gas Turbine and Aeroengine Congress and Exhibition, Stockholm, 1998, pp. GT-52.

[275] M.H. Cho and I. Lee, Aeroelastic analysis of multibladed hingeless rotors in hover, AIAA J. 33(12) (1995), 2348-2353.

[276] M.H. Cho et al., Refined aeroelastic analysis of hingeless rotor blades in hover, J. of Aircraft 334(3) (1997), 408-415.

[277] C. Delle Site and E. Sciubba, Numerical simulation of a splitblade impeller configuration of a centrifugal pump with zerocurvature blades, in: ASME International Mechanical Engineering Congress and Exposition, AES 37, ASME, 1997, pp. 495-505.

[278] D. Dhar and A.M. Sharan, Free vibration analysis of turbine blades using nonlinear finite element method, AIAA J. 35(3) (1997), 590.

[279] M.D. Fitzpatrick et al., Design of a high efficiency industrial turbine blade utilizing third generation single crystal alloy CMSX-10, in: 1997 International Gas Turbine and Aeroengine Congress and Exposition, Orlando, ASME, 1997, pp. GT-429.

[280] P.P. Friedmann and K.A. Yuan, Aeroelastic behavior of composite helicopter blades with advanced geometry tips, in: $\mathrm{Nu}$ merical Methods in Structural Mechanics, AMD 204, ASME, 1995, pp. 31-50.

[281] R. Ganguli and I. Chopra, Aeroelastic tailoring of composite couplings and blade geometry of a helicopter rotor using optimization methods, J. of the American Helicopter Society 42(3) (1997), 218-228.

[282] W.P. Geyer et al., Aeroelastic analysis of transient blade dynamics during shipboard engage/disengage operations, $J$. of Aircraft 35(3) (1998), 445-453.

[283] R.W. Gordon and J.J. Hollkamp, Comparison of damping treatments for gas turbine blades, Proceedings of the SPIE 2720 (1996), 2-12.

[284] L. Guo et al., Modification of a turbogenerator rotor torsional vibration model, J. of Engineering Thermal Energy Transfer (3) (1998), 168-170.

[285] P. Hajela and E. Lee, Rotorcraft subfloor design for enhanced crashworthiness characteristics, Applied Mechanics Reviews 50(11) (1997), S72-80. 
[286] S.R. Hall et al., Helicopter rotor lift distributions for minimum-induced power loss, J. of Aircraft 31(4) (1994), 837-845.

[287] H. Hasemann et al., Investigation of the solidity and the blade vibration behaviour of unshrouded centrifugal compressor impellers with different aerodynamic design, in: 1997 International Gas Turbine and Aeroengine Congress and Exposition, Orlando, ASME, 1997, pp. GT-233.

[288] S. Heath and M. Imregun, An improved single-parameter tiptiming method for turbomachinery blade vibration measurements using optical laser probes, Int. J. of Mechanical Sciences 38(10) (1996), 1047-1058.

[289] B.D. Hines and J.H. Oliver, Geometric decomposition and structural shape modification for turbomachinery blades, in: ASME Design Technology Conference, DE 69/1, Minneapolis, ASME, 1994, pp. 397-402.

[290] M. Hohlrieder and H. Irretier, Comparison of the rotor dynamic and structure dynamic calculation of compressors, in: Cogen-Turbo Power Conference, Vienna, ASME, 1995, pp. CTP-51.

[291] M. Hohlrieder and H. Irretier, Comparison of the rotor dynamic and structure dynamic calculation of compressors, J. of Engineering for Gas Turbines and Power 119(2) (1997), 425429.

[292] Y.M. Huang and C.H. Chang, Stress and deflection analysis for the radial blade of the RCAC system, in: 1994 Pressure Vessels and Piping Conference, PVP 270, ASME, 1994, pp. 119-125.

[293] Y.M. Huang and C.H. Chang, Stress and deflection analysis for the radial blades of the RCAC system, International J. of Refrigeration 20(1) (1997), 55-62.

[294] K. Ishimatsu et al., Numerical simulation for Savonius rotors (running performance and flow fields), Trans. of the Japan Society of Mechanical Engineers, Ser. B 60(569) (1994), 154160.

[295] M. Iwata et al., Study on design technology of multiblade fan (2nd Rep., Basic study on simple numerical model for dynamic analysis of rotating fan shaft system), Trans. of the Japan Society of Mechanical Engineers, Ser. C 62(598) (1996), 2110-2118.

[296] S.M. Jeon et al., Aeroelastic analysis of composite rotor blades in hover, Computers and Structures 66(1) (1998), 5967.

[297] Y. Kadoya et al., Noncontact vibrational measurements technology of steam turbine blade, JSME International J., Ser. C 38(3) (1995), 486-493.

[298] V. Kannan and J.B. Shung, Finite element analysis and design of a trochoidal-type machine without apex seals, $J$. of Mechanical Design, ASME 120(1) (1998), 67-72.

[299] R.A. Komenda et al., Development of a carbon/epoxy filament-wound wing drive shaft for the V-22, in: 51st Annual Forum, American Helicopter Society, 1995, pp. 204-211.

[300] T.L. Krantz, NASA/Army rotorcraft transmission research- a review of recent significant accomplishments, in: 50th Annual Forum, American Helicopter Society, Washington, 1994, pp. 427-440.

[301] D.L. Kunz, Survey and comparison of engineering beam theories for helicopter rotor blades, J. of Aircraft 31(3) (1994), $473-479$.
[302] P. Li and M. Hua, Dynamic response of single-shaft radar antenna mechanical system, J. of Vibration Engineering 11(1) (1998), 102-105.

[303] J.H. Milgram and I. Chopra, Air resonance of hingeless rotor helicopters in trimmed forward flight, $J$. of the American Helicopter Society 39(4) (1994), 46-58.

[304] R.L. Murphy, Summary report on radial and axial vent hole analysis on 43 inch conventional generator rotor, in: 57th Annual American Power Conference, Chicago, 57-2, 1995, pp. 986-993.

[305] B. Newland, Structural qualification of a main rotor yoke using the finite element analysis method, in: 50th Annual Forum, American Helicopter Society, Washington, 1994, pp. 13911402.

[306] H. Nickel et al., Experimental and numerical investigation of the deformation behaviour of a thermal mechanically loaded model turbine blade on IN 792 DS, in: 1997 ASME Pressure Vessels and Piping Conference, 359, ASME, 1997, pp. 275280.

[307] C.A. Pistner et al., Influence of bearing support structures on shaft vibration of large hydraulic pump/turbines, in: International Conference on Hydropower, 3, ASCE, 1995, pp. 26202629.

[308] T. E. Purcell, Dynamic stress analysis of gas turbine rotor airfoils using thermoelastic techniques, Experimental Techniques 20(3) (1996), 9-13.

[309] J.S. Rao et al., Vibration analysis of rotating cambered helicoidal turbomachine blades, in: 1997 International Gas Turbine and Aeroengine Congress and Exposition, Orlando, ASME, 1997, pp. GT-299.

[310] J.S. Rao et al., Mixed shell element for cambered helicoidal blades and dynamic stresses due to aerodynamic excitation, in: International Gas Turbine and Aeroengine Congress and Exhibition, Stockholm, 1998, pp. GT-356.

[311] M.J. Roemer et al., On site modal testing of low pressure turbine blade rows, Sound and Vibration 28(5) (1994), 16-22.

[312] B. Ross et al., Inordinate failures of rotating biological contactor (RBC) drive shafts in wastewater treatment plant service worldwide, International J. of Pressure Vessels and Piping 59(1/3) (1994), 197-209.

[313] G.L. Rossi et al., Experimental tuning of resonance frequencies of a turbine blade by a laser scanning vibrometer, in: 16th International Modal Analysis Conference, Santa Barbara, 1998, pp. 1758-1762.

[314] F.A. Tasker and Z. Yu, Identification of nonlinear helicopter rotor structural dynamics, in: 35th Structures, Structural Dynamics and Material Conference, AIAA, 1994, pp. 1-7.

[315] M. Toossi et al., Determination of AH-64 airframe in-flight modal frequencies using rotor control-induced excitations, in: 50th Annual Forum, American Helicopter Society, Washington, 1994, pp. 1287-1302.

[316] A.L. Tracy and I. Chopra, Aeroelastic analysis of a composite bearingless rotor in forward flight using an improved warping model, J. of the American Helicopter Society 40(3) (1995), 80-91.

[317] H. Yeo and I. Chopra, Effects of modelling refinements on coupled rotor/fuselage vibration analysis, in: Annual Forum Proceedings, American Helicopter Society, 1, Washington, 1998, pp. 489-501. 
[318] Z.C. Zheng et al., Aeroelastic response of a coupled rotor/fuselage system in hovering and forward flight, Archive of Applied Mechanics 69(1) (1999), 68-82.
[319] C. Zou, Modal analysis of lateral vibration of cam engine shafting system, J. of the East China Shipbuilding Institute 12(1) (1998), 41-50. 

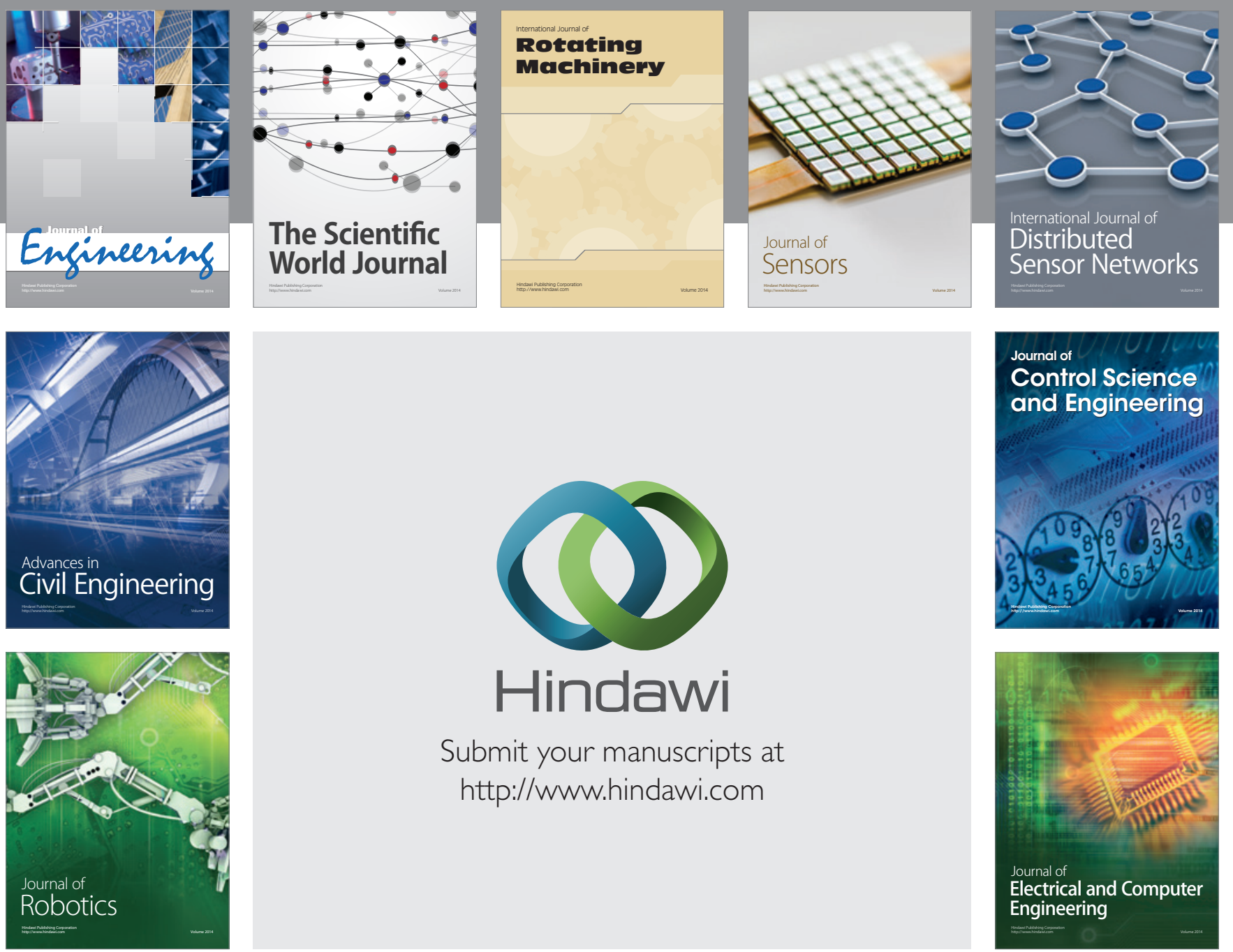

Submit your manuscripts at

http://www.hindawi.com
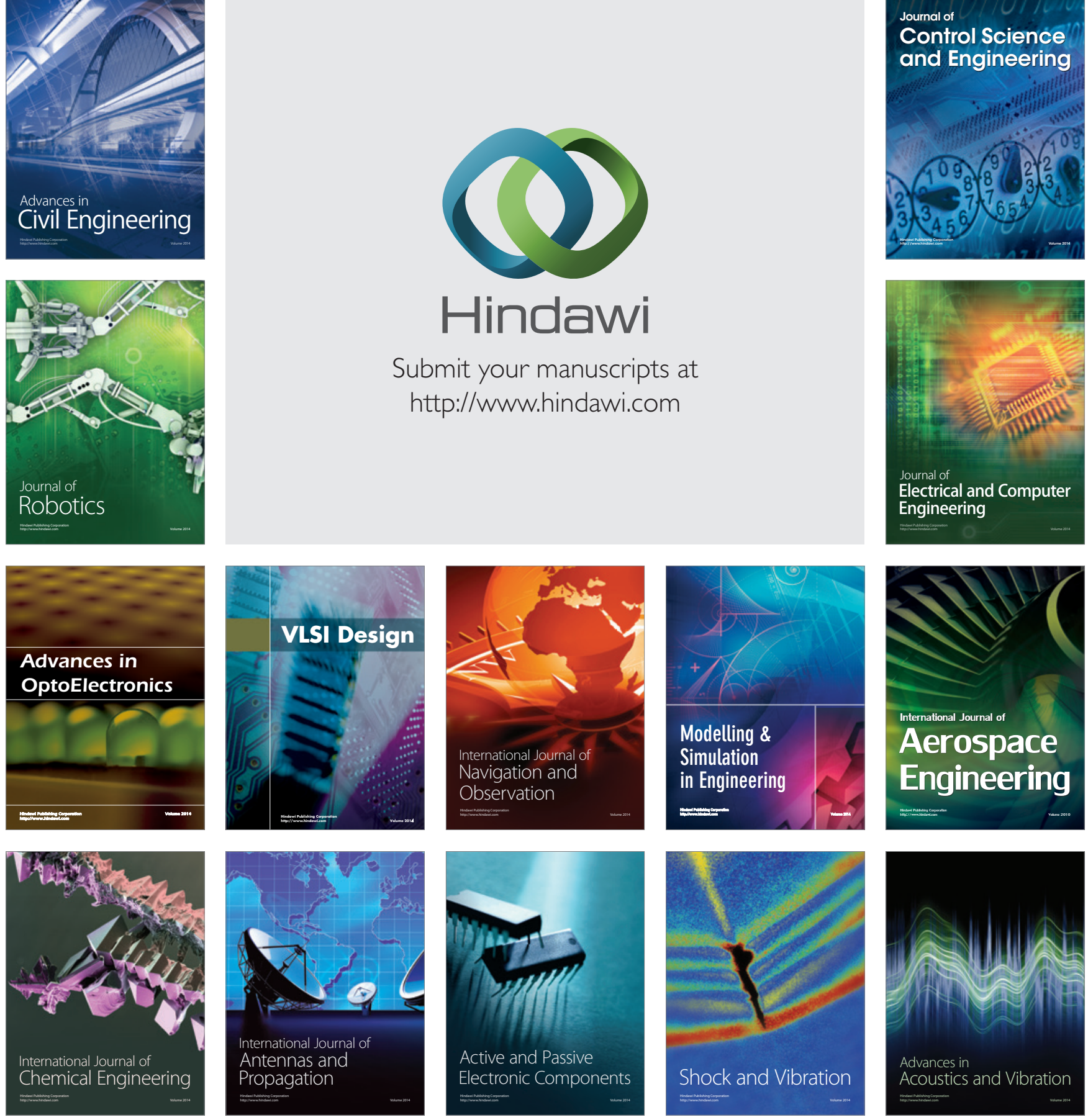